\title{
THE POLICE SERVICE AS A GUARDIAN OF PUBLIC SECURITY AND PUBLIC ORDER IN CONTEMPORARY POLAND
}

One of the most significant elements that make and determine the quality of the internal safety of the state are public safety and public order. The concepts of public safety and public order are often combined into one term, i.e. public safety and order. While bearing in mind that public order in some of its manifestations falls within the framework of public safety, it should be noted that the use of the above-mentioned combined concept is, due to the clearly distinguished designations of both concepts, unjustifiable. ${ }^{1}$ The requirements of effective operation in the scope of maintenance and restoration of public safety and public order are an important argument for a separate use of each of the terms (what is meant here is, first of all, a diversified nature of legal and institutional measures that could be used). In terms of definition, it can be assumed that "public safety is such a state, based on legal standards, inside the State in which the conditions for efficient functioning of the State organisation pursuing common, supraindividual objectives, are ensured; where duties and rights of individuals living in the organisation are effectively enforced (with a special regard to human life, health and property) and there are resources and mechanisms of execution facilitating an effective reaction to the situations upsetting such state". ${ }^{2}$ In turn, public order "is the state recognized as desirable and consistent with legal and non-legal standards, in which social existence rules are observed, which ensures high quality of public space as well as of facilities, equipment and infrastructure designated for common use, which enables safe functioning of individuals and social communities and satisfaction of their needs". 3 Police is one of the most important instruments used to main$\operatorname{tain}^{4}$ the desired level of public safety and public order in Poland. The Police Act of 6 April 1990 provides for the creation of Police as a uniformed and armed force serving the society and designated for protection of people's safety and maintenance of

1 There is an area where the scopes of both concepts overlap e.g. if the obligated entity does not clean the road when there is a glazed frost, it will thus not only disturb public order, but also cause a threat to public safety. There area also situations where the two concepts do not overlap, e.g. when the obligated entity does not mark its plot of land with a plate showing the number of the plot. Then, it disturbs public order, but cannot be really recognised as disturbing public safety. A similar situation occurs when night peace is disturbed.

2 W. Fehler, Bezpieczeństwo wewnętrzne wspótczesnej Polski. Aspekty teoretyczne i praktyczne, Warszawa 2012 p. 43.

3 Ibidem, p. 50.

4 See: S. Pieprzny, Policja. Organizacja i funkcjonowanie, Warszawa 2007, p. 26. 
public safety and order. ${ }^{5}$ As Andrzej Misiuk rightly states, the Police service functions based on four principles: lawfulness, political indifference, hierarchic subordination, territorial division of the state as the basis for its general organisational structure. ${ }^{6}$ The basic statutory tasks of Police are as follows: ${ }^{7}$

- to protect human life and health against illegal attempts at violating those values;

- to protect public safety and order, including to ensure peace and quiet in public places and in the means of public transport and mass transit, in road traffic and on waters designated for general use;

- to initiate and organise actions aimed at crime and misdemeanor prevention and at prevention of crime-related phenomena and to cooperate in this scope with state and local government authorities and social organisations;

- to detect crimes and misdemeanors and to prosecute perpetrators thereof;

- to supervise municipality (city) guards and specialist armed crime protection units;

- to control the observance of order-related and administrative rules in effect at public places;

- to cooperate with the police forces of other states and their international organisations;

- to keep a database containing DNA information.

The Police force comprises three types of services: criminal, crime prevention and support services. The organisational structure of the Police comprise National Police Headquarters, Regional headquarters, County and municipal headquarters, stations, posts and patrol beats. Apart from the structures of headquarters and stations, the Police force also includes other autonomous organisational units: the Police College, training centres, schools of policing, independent crime prevention squads and sub-squads, anti-terrorist squads, and development and research institutes. ${ }^{8}$ The Police forces are headed by the Chief of Police, reporting to the minister in charge of internal affairs, appointed and recalled by the President of the Council of Ministers, at the request of the minister.

The Chief of Police is the central authority of the government administration, in charge of the matters of human safety and maintenance of public safety and public order. As the central authority of the government administration, the competence of the Chief of Police covers the whole area of the Republic of Poland. This is confirmed by the content of Article 5, paragraph 2 of the Police Act stating that the Chief of Police is the superior of all Police officers. This means that he holds the supreme position in the hierarchic structure of Police. The subordination of the Chief of Police to the minister in charge of internal affairs is tightly connected with his competence in matters of protection and safety of people and of maintaining public safety and public order. The subordination of the Chief of Police is expressly underlined by the Police Act in the

5 See: art. 1.1, Ustawa z dnia 6 kwietnia 1990 r. o Policji, as amended, "Journal of Laws" 2011, No. 287, item 1687.

${ }^{6}$ See: A. Misiuk, Administracja porzqdku i bezpieczeństwa publicznego. Zagadnienia ustrojowo-prawne, Warszawa 2008, p. 96.

7 See: Art. 1.2, Ustawa z dnia 6 kwietnia 1990 r. o Policji, op. cit.

8 See: ibidem, art. 4.3 . 
Chart 1. General organisational structure of the Police force

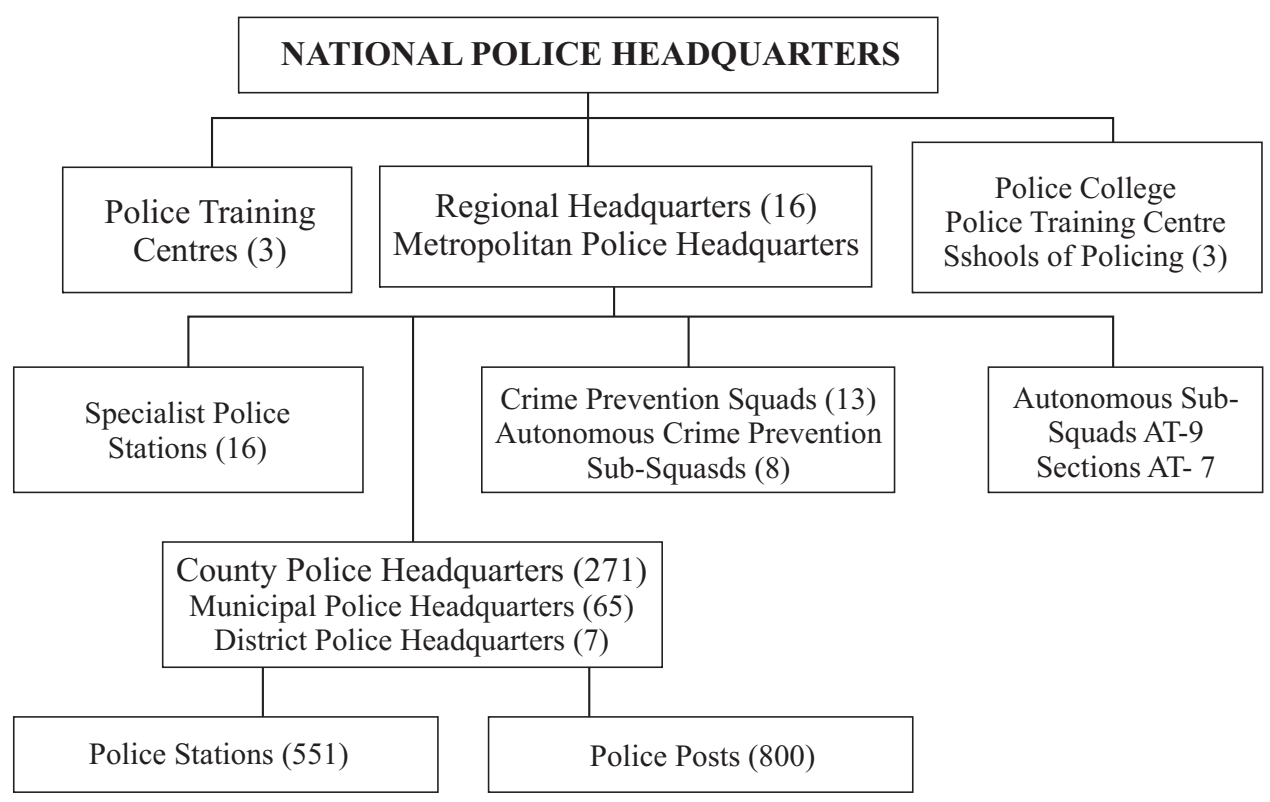

Source: Author's study on the basis of the materials of the National Police HQ.

provisions defining the manner in which appointment to this position in the Police structure is made. The subordination does not apply to personal matters only. It manifests itself, first of all, in the form of implementation of the government's policy in the scope of public safety and public order. It is the minister in charge of internal affairs ${ }^{9}$ that entrusts tasks connected with the implementation of such policy to the Chief of Police. He also defines the directions of the Police activities and development, in line with the policy of the government, whereas the Chief of Police submits to him reports relating to the policy implementation. Pursuant to Art. $6 \mathrm{~g}$ of the Police Act, the Chief of Police carries out his tasks with the assistance of the National Police Headquarters (NPHQ). It is a unit that is superior to all the Regional Police Headquarters and Police schools and consists of organisational cells that are subordinate, by task, to the Chief of Police and his three deputies. Offices are basic modules of the NPHQ structure; they are divided into departments which are, in turn, divided into sections and teams. ${ }^{10}$ Offices are headed by directors and their deputies, and the departments are managed by heads of the departments and their deputies. Depending on the nature of tasks carried out

9 In accordance with the present legal state created by the Ordinance of the President of the Council of Ministers of 18 November on the detailed scope of activity of the Minister of Internal Affairs. See: "Journal of Laws" 2011, No. 248, item 1491.

10 In accordance with the Act, the organisational structure, the organisation management and the tasks of the organisational units of the National Police Headquarters are defined by the Chief of Police by adopting respective by-laws. Currently (in 2012) it is based on: Zarządzenie nr 749 Komendanta Głównego Policji z dnia 27 maja 2010 r. w sprawie regulaminu Komendy Głównej Policji, as amended, "NPHQ Official Gazette" 2010, No. 6, item 20. 
within the department and on the staff employed, there are sections created, headed by managers. ${ }^{11}$ The following activities pertain to the scope of operation of the Chart 2.

\section{Chart 2. Organisational Structure of the National Police Headquarters}

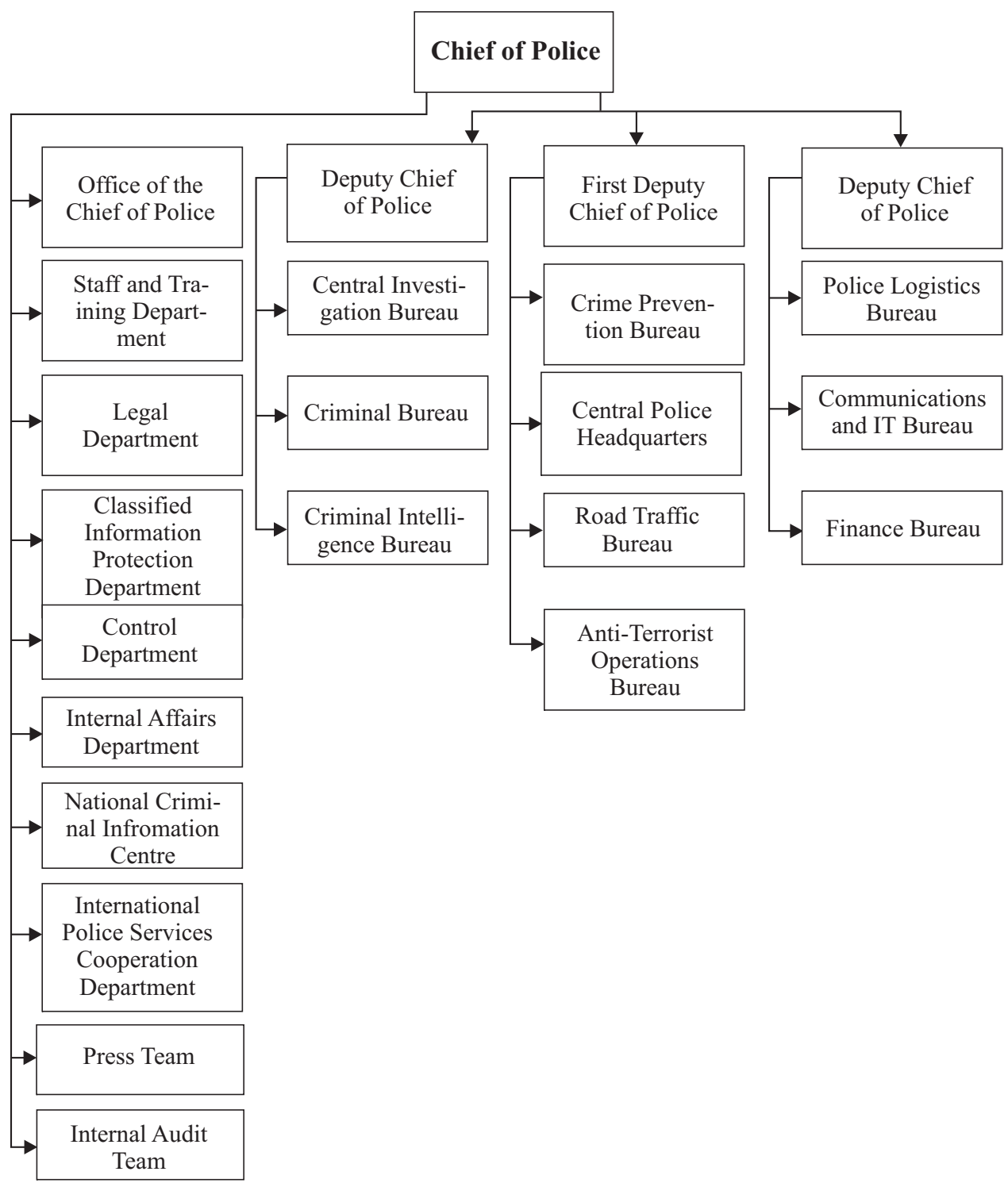

Source: Structure of the National Police Headquarters, http:/www.info.policja.pl/portal/inf/922/49463/ (22 June 2012).

11 See: Zarządzenie Nr 1041 Komendanta Głównego Policji z dnia 28 września 2007 r. w sprawie szczegółowych zasad organizacji i zakresu działania komend, komisariatów i innych jednostek organizacyjnych Policji, as amended, "NPHQ Official Gazette" 2007, No. 18, item 135. 
The activites of the National Police Headquarters are: ${ }^{12}$

- to initiate and coordinate the activities of the Police services in the scope of goals defined as statutory Police tasks, and to supervise the performance of those tasks;

- to create the conditions for efficient and effective operation of the Police services in the scope of identification and combating transborder, organised and drug-related crime;

- to counteract and physically combat terrorism, to coordinate and supervise Police operations in that scope;

- to detect and prosecute business ventures and financial operations aimed at introducing trading funds generated from criminal activities into legal turnover, to detect and prosecute bribery-related offences connected with a large size of illegally obtained gains or causing substantial damage to the functioning of public administration or other state institutions in economic turnover;

- to implement programmes of protection of crown witnesses and their close relatives and partners;

- to analyse crime-generating phenomena and to develop programmes of preventing and counteracting those phenomena, as well as to assist in the implementation of such undertakings by the Police units;

- to initiate, organise, coordinate and supervise the implementation of tasks by the Police units in the event it is necessary to take measures to ensure public safety and order as part of the policing operations being carried out;

- to organise, supervise and coordinate the policing negotiation system;

- to directly cooperate with foreign police forces or their international organisations and with the bodies and institutions authorised to prevent and combat crime, to coordinate the Police operations in that scope;

- to organise, coordinate and supervise the activity of the services on duty;

- to initiate, coordinate, supervise and inspect the performance of Police tasks in the scope of organisation and performance of duty service in convoys or in premises for the detained, to coordinate, supervise and inspect the activities of Police in the scope of preventing and combating petty offences;

- to cooperate with legal protection authorities, public administration authorities and social organisations in the scope of crime prevention and combat;

- to initiate, coordinate and supervise Police activities in the scope of implementation of the tasks arising from international agreements, arrangements and conventions relating to crime prevention and control;

- to control the efficiency of management of the Police units and cells in the NPHQ;

- to create human resources policy in the Police force and to ensure HR service of policemen and employees in the scope reserved for the Chief of Police;

- to make law, to provide legal assistance and legal information in the scope connected with pursuance of Police tasks;

- to organise and work on the development of communications systems and information technology systems, the protection of information in the communications and IT, tele-transmission, telecommunications and radio-communications systems;

12 See: Zarządzenie nr 749 Komendanta Głównego Policji z dnia 27 maja 2010 r. w sprawie regulaminu Komendy Głównej Policji, as amended, "NPHQ Official Gazette” 2010, No. 6, item 20. 
- to organise IT systems and to coordinate actions connected with introducing the data collected in the newly-created IT systems into the information circulation system;

- to perform the tasks arising from the laws relating to the collection, processing and transmission of criminal information, on the basis of separate laws. ${ }^{13}$

It must be pointed out that the scope of operation of the National Police Headquarters is not precisely specified in terms of tasks enumeration; it is an open list and only main areas of interest are indicated. As far as the regional level is concerned, the Police Act in Article 6 defines the government administration authorities in a province that are competent in matters of human safety protection and public safety and order maintenance. Apart from the governor, it mentions the chief of provincial Police force, the chief of the county (municipal) Police force, the chief of the Police station. The reform of public administration carried out in 1998 brought about, among others, changes in the structure of the authorities responsible for ensuring public safety and order. The most important change was the inclusion of the Police force into the structure of combined administration and linking it with local government administration. The Police in the province is headed by the Chief of Provincial Police appointed and recalled by the minister in charge of internal affairs on recommendation of the Chief of Police, after consulting the governor. The Chief of Provincial Police performs the tasks imposed on him using the assistance of the Provincial Police Headquarters (PPHQ). The PPHQ organisational structure corresponds to the National Police Headquarters structure, also with regard to tasks pursued. The Provincial Police Headquarters is a unit superior to the County Police Headquarters and consists of organisational sections subordinated, by task, to the Chief of Provincial Police and his deputies. ${ }^{14}$ The PPHQ basic structural elements are departments, divided into sections and teams. The PPHQ is responsible for: ${ }^{15}$ initiation and coordination crime prevention programmes of the Police units, for carrying out operational-identification and investigation-prosecution activities, as well as for cooperation with foreign police forces or their international organisations. It is also responsible for planning, organising and coordinating tasks relating to the carrying out of policing operations, conducted within the area of a province; organising, coordinating and supervising the activity of the services on duty in the subordinate Police units, and for coordinating the activities of county Police headquarters in the scope of protection, safety and order in road traffic. The PPHQ responsibilities are also connected with co-acting in the scope of tasks performed in the province by the NPHQ cells in the scope of combating organised crime; supervising actions of city and municipality

13 Pursuant to the content of Art. 5 of the Act of 6 July 2001 on the Collection, Processing and Transmission of Criminal Information (consolidated text: "Journal of Laws" 2010, No. 29, item 153), the Chief Commander of the Police is the government administration authority competent in the matters of collecting, processing and transmitting criminal data. The Chief Commander performs these tasks with the assistance of the National Criminal Information Centre, being an organizational section in the National Police Headquarters.

14 Pursuant to Art. 6 b of the Police Act of 6 April 1990, the Chief Commander appoints up to three deputies of the Provincial Police Commander, on the latter's recommendation.

15 See: Zarządzenie Nr 1041 Komendanta Głównego Policji z dnia 28 września 2007 r. w sprawie szczególowych zasad organizacji i zakresu działania komend, komisariatów i innych jednostek organizacyjnych Policji, as amended, "NPHQ Official Gazette" 2007, No. 18, item 135. 
guards and of companies or institutions engaged in protection of people and property; cooperating with legal protection authorities, public administration authorities and social organizations active in the province in the scope of crime prevention and combat; controling the efficiency of operation of the subordinate Police units; organising, operating and technically maintaining the communications and IT systems used in the Police units in the province; and with providing transport and quartermaster management and to supervise the subordinate Police units.

The scope of activities of the Provincial Police Headquarters as well as of the National Police Headquarters has been defined in an "open-ended" list and comprises mainly the tasks of initiating and coordinating crime prevention programmes for Police units as well as coordinating the operational intelligence and investigation and prosecution activities undertaken by the subordinate Police units. It must be added that planning, organising and coordinating tasks relating to the carrying out of police operations during mass events and social protests as well as planning, organising and coordinating actions during the occurrence of natural calamities and technical failures, is an important area of activity of the PPHQ. The NPHQ also supervise preparation of the subordinate Police units for the carrying out of tasks in the conditions of threat to public safety and public order in the states of exception defined in the Constitution. ${ }^{16}$ As regards the county, it should be noted that the Chief of County Police is appointed and recalled by the Chief of Provincial Police, after consulting the head of the county's administration. On recommendation of the Chief of County Police, the Chief of Provincial Police appoints and recalls deputies of the Chief of County Police.

The organisational structure of the County Police Headquarters (CPHQ) corresponds, in terms of pursued tasks, to the structure of the Provincial Police Headquarters. CPHQ is a superior unit to the Police Station and consists of organisational sections subordinated, in terms of tasks, to the Chief of County Police and his deputies. Departments are basic structural elements of the CPHQ, which are divided, in turn, into sections and teams. The following tasks fall within the scope of activities of the County Police Headquarters: ${ }^{17}$

- to create and implement, in cooperation with local government authorities and non-governmental organisations and institutions, crime prevention programmes;

- to carry out operational intelligence as well as investigation and prosecution activities in order to discover offenses and efficiently detect their perpetrators;

- to organise, coordinate and supervise the operation of the services on duty in the subordinate Police units;

- to plan and organise County Police Headquarters' own activities connected with pursuance of tasks in the scope of ensuring public order and public safety when carrying out actions to ensure safety and order in traffic on public roads through directing the traffic and controlling it;

16 See: B. Wiśniewski, Charakterystyka Policji, in: Wspótczesny wymiar funkcjonowania Policji, eds. B. Wiśniewski, Z. Piątek, Warszawa 2009, p. 32-33.

17 See: Ruling No. 1041 of the Chief Police Commander of 28 September 2007 on Detailed Rules of Organisation and the Scope of Operation of Police Headquarters, Stations and Other Units, as amended, "NPHQ Official Gazette" 2007, No. 18, item 135. 
- to pursue tasks connected with liquidation of the effects of road events and with securing traces and evidence for the purposes of legal proceedings;

- to analyse crime-related phenomena and identified crime threats, with particular regard to pathological phenomena;

- to control and appraise the operation of the subordinate Police units;

- to operate and technically maintain the communications and IT systems at the CPHQ and in the subordinate Police units and to coordinate those systems in cooperation with the relevant PPHQ cell;

- to ensure necessary logistic and technical provisions for the purposes of CPHQ and the subordinate Police units.

At the level of county organisation, the most important task of Police is to organise, coordinate and carry out patrol, intervention, convoy and crime protection actions. A very important task is also to combat crime by discovering, preventing and fighting social pathology phenomena, in particular among children and youth. The lowest structural link in the Police structure that is subordinate to the CPHQ is the police station.

The Police station is directed by the chief of the Police station appointed and recalled by the Chief of County Police, after consultation with the territorially relevant head of the village, mayor or president of the city (consultation is not required in respect of the chiefs of specialist Police stations). In must be added that the Chief of County Police appoints deputies of the chief of the Police station, on the latter's recommendation. The organisational structure of the Police Station corresponds, in terms of pursued tasks, to the CPHQ structure. The Police Station consists of organisational sections subordinated, by tasks, to the Chief of the Police Station and his deputies. Divisions (criminal, crime-prevention, support) are basic organisational elements of the Police Station and are divided into sections and teams, headed by managers. The following are the tasks falling into the scope of operation of the Police station and specialist Police station: $^{18}$

- to carry out the tasks of crime-prevention service of Police;

- to identify crime threats and to carry out operational intelligence as well as investigation and prosecution activities in order to prosecute perpetrators of crimes and offenses, and also to conduct searches for persons and things and to identify persons, in cooperation with other Police units;

- to cooperate with local government;

- to pursue, to the necessary extent, the tasks of support service.

The Chief of County (City) Police may create patrol beats and Police posts. The chief officer of the Police patrol beat and the chief officer of the Police post are appointed and recalled by the chief of county (city) Police, after consulting the head of the village (mayor or president of the city). The following are, in particular, the tasks of the Police patrol beat and the Police post: to counteract crime and petty offense perpetra-

18 Pursuant to Art. 8 of the Police Act, the Voivodeship Police Commander in agreement with the Chief Police Commander creates, if need may be, a railway, maritime, air- or other specialist station. Commanders of specialist stations report to the territorially competent voivodeship commander of the Police. A specialist station commander is appointed and recalled by the voivodeship commander of the Police. 
tion in public places; to discover, prevent and combat the phenomena of social pathology, in particular among children and youth; to create in local communities a positive image of Police and of the actions taken by Police with the view of ensuring public safety and public order; to discover crimes and petty offences and to detect their perpetrators; to pursue administrative and order-related tasks; and to cooperate with the local government and other entities that act for public safety and order. ${ }^{19}$

In the structure of a Police post, apart from the position of the manager there is also: a section for crime prevention s and a section for criminal affairs. As far as a Police patrol beat is concerned, in its structure there is the chief of the patrol beat, appointed by the Chief of County Police, and patrol beat constables. In the Police force there are also Police Crime-Prevention Squads (PCPS) and Police Autonomous Crime-Prevention Sub-Squads (PACPSS) operating, with approximately 6.6 thousand full-time jobs. These units are mainly prepared for team actions within the framework of compact sub-squads. Their goals are:

- to perform tasks connected with the carrying out of police operations in the situations of threat to public safety and order;

- to participate in the actions of blockage and chasing after a dangerous criminal;

- to protect public order during statutorily defined states of exception, natural calamities and technical breakdowns;

- to protect safety and order during visits of representatives of foreign countries;

- to protect safety and order during legal public gatherings and during mass events and social protests;

- to restore public order in the event of collective violation of law;

- to support field units of Police in patrolling actions and patrolling-intervention actions.

PCPSs and PACPSSs of the Police force are run by commanders reporting to the chief of provincial (metropolitan) Police. The basis for PCPS and PACPSS organisational structures are companies, platoons, troops and teams. The Police Crime Prevention Squads (13 units) and the Police Autonomous Crime Prevention Sub-Squads ( 8 units) constitute a reserve of the Chief of Police designated for action in the territory of the Republic of Poland. Where the operations carried out require use of crime prevention squads from a few provinces, their concentration is made on the basis of a decision of the Chief of Police. ${ }^{20}$ Antiterrorist sub-squads are also subordinated to chiefs of provincial police forces. ${ }^{21}$ Their tasks include: 1) physical combat of terrorism by carrying out reconnaissance and combat operations using anti-terrorist tactics; 2) carrying out miner and pyrotechnic operations; 3 ) carrying out other tasks requiring the use of specialist forces and means or special operational tactics; 4) supporting actions of other divisions of the Police force and internal security services in the situations requiring the

19 See: Wytyczne Nr 5 Komendanta Głównego Policji z dnia 20 sierpnia 2004 r. w sprawie zasad organizacji i funkcjonowania posterunku Policji, as amended, "NPHQ Official Gazette" 2004, No. 16, item 105.

20 See: Decyzja nr 809 KGP z 14 listopada 2007 r. w sprawie utworzenia oddziałów prewencji Policji i samodzielnych pododdziałów prewencji Policji, as amended, "NPHQ Official Gazette" 2008, No. 21, item 158.

21 The issues of the functioning and organization of anti-terrorist units are regulated by non-published decisions of the Chief Police Commander. 
use of special forces and methods of operation. This means, in practice, detaining, first of all, particularly dangerous persons on order of the criminal service of Police, the Central Bureau of Investigation and other services and authorities; supporting chase operations, strengthening the protection of important persons, supporting convoy services and the court police during convoys and trials with the participation of particularly dangerous criminals. At some PPHQs there are Police Autonomous Anti-Terrorist Sub-Squads operating, with approximately 55 full-time officer's jobs. They are located in Szczecin, Gdańsk, Białystok, Łódź, Poznań, Wrocław, Katowice, Kraków, Rzeszów. In the other provincial cities there are Anti-Terrorist Police Sections (ATPS) with 19-36 policemen each. PATSSs operate in Kielce, Radom, Lublin, Gorzów Wielkopolski, Olsztyn, Bydgoszcz. PATSSs were established on the basis of special task forces existing at the PPHQ in the above-mentioned cities. The Police force has also the Implementation Department at the Metropolitan Headquarters and the Police Anti-Terrorist Bureau (PATB) which is part of the organisational structure of the NPHQ. PATB has 270 officers and its principal task is to counteract terrorism and to fight it physically and to recognise, coordinate and supervise the Police operations in this scope. ${ }^{22}$

Within the Police organisational structures there is a system of schools of policing: the Police College in Szczytno, the Police Training Centre in Legionowo, the School of Policing in Piła, the School of Policing in Słupsk, and the School of Policing in Katowice. These schools provide specialist vocational training to officers and employees of Police as well as to the Border Guard, the Government Protection Bureau, the Internal Security Agency.

The Police College in Szczytno is a public vocational school of higher education for the state services as defined in the Act of 27 July 2005 on Higher Education, supervised by the minister in charge of internal affairs ${ }^{23}$ and an organisational unit of the Police force as defined in the Police Act of 6 April 1990. The school carries on higher studies for civilians, Police officers and officers of other services. Also, this school of higher education organises and conducts professional training courses for policemen, vocational training courses for university graduates, specialist courses of professional development as part of the Central European Police College and the European Police College (CEPOL). The establishment in Szczytno conducts training courses for policemen from other states as well. Apart from instruction, the school carries on research and development activities within the disciplines connected with fighting organised crime as well as with the organisation and tactics of police operations. The Police College in Szczytno is the only Police school the graduates of which are granted the first officer's rank. ${ }^{24}$ The Police College realises, among others, educational projects for police offi-

${ }^{22}$ More details on this topic: Biuro Operacji Antyterrorystycznych, http://www.policja.pl/portal/pol/560/Biuro_Operacji_Antyterrorystycznych.html (5.07.2012).

${ }^{23}$ See: Ustawa z dnia $2 \overline{7}$ lipca 2005 r., Prawo o szkolnictwie wyższym, as amended, "Jourrnal of Laws" 2005, No. 164, item 1365.

${ }^{24}$ See: Rozporządzenie Ministra Spraw Wewnętrznych i Administracji z dnia 19 lipca 2007 r. w sprawie mianowania policjantów na stopnie policyjne, as amended, "Jourrnal of Laws" 2007, No. 145, item 1017. 
cers, consisting in providing professional knowledge and skills required at officer's corps positions, as well as training projects for policemen and employees, consisting in preparing them to perform service or work at managerial and autonomous positions. Another establishment, in terms of the scope of activity, is the Police Training Centre (PTC) in Legionowo, with three instruction centres operating within its framework: the International Specialist Training Centre, the centre of guide training and police dogs training in Sułkowice and the maritime police training centre in Kal at the Mazurian Lake District. In the PTC structure there is also a Central Police Library, with 270,000 volumes of specialist literature. Among the participants of the training courses organised in the Centre there are not only policemen, but also employees of other services of the ministry of the interior and of non-ministerial institutions. The PTC also functions as the conference facility of Police. The School of Policing in Stupsk, the organisational beginnings of which date back its to $1945,{ }^{25}$ specialises in training policemen of the crime prevention force. Also, the establishment in Słupsk conducts specialist training courses. These courses prepare policemen to do tasks at the positions requiring more comprehensive knowledge and professional skills (as required to perform managerial functions), e.g. a course of training on how to conduct interrogation using the FBI methods, a development course for press spokesmen and officers, the course for the Police officer on duty, for the chief patrol beat officer, for the platoon commander, or for the chief officer of the patrol and intervention section. The school in Stupsk offers various courses of vocational development, among others, courses for officers on duty, patrol beat officers, policemen of the patrol and intervention services and also courses teaching how to use the Police information technology systems and courses on public relations. The School of Policing in Słupsk is the only school that trains shooting instructors for police units. ${ }^{26}$ The school also prepares policemen for service in the Polish Police Special Unit in Kosowo as part of the UN Interim Administration Mission. Not only policemen, but also officers of the Border Guard, the Military Police and customs officers and policemen from other countries broaden their knowledge in the school in Słupsk. The School of Policing in Piła has existed from 15 September 1954. Currently, it provides training at the basic level as part of vocational development, its field of specialty being the training of criminal service policemen appointed to serve in sections engaged in operational as well as investigation and prosecution work. The school also provides basic vocational course of training, preparing policemen to serve at basic executive positions in the crime prevention division. An important element of the school's activity are specialist courses for policemen engaged in investigation, operational work and in fighting economic crime. ${ }^{27}$ As far as the School of Policing in Katowice is concerned, in existence since 1 February 1999, it specialises in training policemen of the crime prevention division, serving in the conditions of large urban agglomerations. The school conducts the following types of training: basic vocational

25 From 1945 to 1990 this instutution educated, in various organisational forms, staff for Milicja Obywatelska (MO) [Citizen's Militia] forces.

26 See: Zakres szkolenia, http://slupsk.szkolapolicji.gov.pl/indexmain.php?act=szk\&det=zak (5.07.2012).

27 See: Zakres szkolenia, http: pila.szkolapolicji.gov.pl/joomla/o-szkole.html (5.07.2012). 
training for policemen who have undergone candidate's training, vocational development in the form of numerous specialist courses for, among others:

- the duty service of the Police organisational units;

- policemen performing defense-related tasks;

- policemen carrying out the activities in administrative proceedings;

- policemen acting as public prosecutors;

- policemen conduting preparatory proceedings;

- police officers responsible for disciplinary matters;

- chief patrol beat officers;

- policemen undertaking interventions against aggressive and dangerous persons;

- persons operating the National Police Information System in the scope of crime prevention issues;

- persons using the information resources of the National Criminal Information Centre in the scope of operational and investigation issues. ${ }^{28}$

It should be noted that there are also training centres operating in the Police Provincial Headquarters with the task to provide short-term specialist training courses for PPHQ organisational units. They also constitute the base where official briefings at the PPHQ level are made. In the police school system there are slightly over 800 officers employees.

The Police force, for the reason of a broad range of statutory tasks, has a definite potential in terms of staff and equipment. In Polish Police there are currently (in 2012) 97,421 policemen (of which 13 thousand are women officers) and 24,895 members of civil staff employed (of which 11,839 belongs to the civil service corps). One police officer falls to 384 inhabitants of Poland. The number of full-time jobs in the Police force in 2012 is 102,309 thousand officers. The majority of the policemen serve in crime prevention division $-59,769$, which accounts for approximately $61 \%$ of all the Police officers. In criminal services there are 31,965 policemen employed - which accounts for $33 \%$, and in support services 2,941 officers, i.e. $4 \%$. Within the command of the Police organisational units there are 1,817 persons (which accounts for $2 \%$ of the entire formation). There are also: $:^{29} 13,050$ officers; 43,522 warrant officers; 31,683 assistant officers and 9,060 privates.

With regard to age, the prevailing group among Polish policemen are people in the age of 31-40 years - 46,027 persons, next group are policemen in the age of 41-50 $-28,553$ persons. The next to follow is the group in the age of $25-30$ years $-14,850$ policemen, police officers in the age over 50 years $-4,798$ persons, and in the age of up to 25 years $-3,193$ persons. Most of policemen, i.e. 55,609, completed secondary educa-

28 See: Informacje o szkole, http://katowice.szkolapolicji.gov.pl/?page_id=37 (3.07.2012).

29 In Police there are the following corps and police ranks: (1) in the corps of Police generals: inspector general of Police, chief inspector of Police; (2) in the corps of Police senior officers: senior inspector of Police, inspector of Police, assistant inspector of Police; (3) in the corps of Police junior officers: chief superintendent of Police, superintendent of Police, assistant superintendent of Police; (4) in the corps of Police warrant officers: staff warrant officer of Police, senior warrant officer of Police, warrant officer of Police, assistant warrant officer of Police; (5) in the corps of Police assistant officers: staff sergeant of Police, senior sergeant of Police, sergeant of Police; (6) in the corps of Police privates: senior constable, constable. 
tion. 39,064 persons completed university studies. 2,546 serving policemen hold postsecondary school diplomas and 202 policemen have basic and vocational education. With regard to the length of service in the police force, the breakdown is as follows:

- up to 3 years of service $-8,439$ policemen;

- from 3 to 10 years of service $-33,429$ policemen;

- from 11 to 15 years of service - 18,325 policemen;

- from 16 to 20 years of service - 15,779 policemen;

- from 21 to 30 years of service $-20,308$ policemen;

- more than 30 years of service $-1,141^{30}$ policemen.

Most of police officers are young and middle-aged people. They represent $74 \%$ of all the headcount of Police officers. Art. 25 of the Police Act requires that in order to be admitted to service in this formation a person must be a Polish citizen of impeccable conduct, without criminal record, he/she must enjoy full public rights, have at least secondary education $^{31}$ and physical and mental capabilities to serve in the armed formations subjected to a special official regime which he/she is willing to submit to. The principles governing the selection and conduct of the qualification procedure for the service in the Police force have been defined in the Ordinance of the Minister of Internal Affairs. ${ }^{32}$ Selection for the service is carried out by periodic actions. It is commenced by an announcement of the Chief of Police, setting the dates and limits of admissions.

In performing the activities described in the Police Act of 6 April 1990, Police officers, acting in the interest of the safety of the state and its citizens, have specialist equipment and gear, including means of transport, at their disposal. To have appropriate number and types of vehicles, motor boats and other road transportation vehicles is indispensable for ensuring the required high mobility of the Police services that pursue essential, in terms of the interest of the state, tasks connected with security and public order protection. The issue of ensuring mobility has a direct impact upon: ${ }^{33}$

- ensuring high, noticeable to citizens, effectiveness of protection of human life and health and property against illegal attempts at these interests;

- increasing the effectiveness of policemen's work in crime prevention, operational, investigation and prosecution actions;

30 See: Stan zatrudnienia, http://www.info.policja.pl/portal/inf/860/47710/Stan_zatrudnienia_na_dzien_1_stycznia_2012_r.html (1.07.2012).

31 The Chief Provincial Police may consent to admitting a candidate who does not have secondary education to Police crime prevention squads, if it has been found in the course of the qualification procedure that the candiate shows special abilities to serve in the Police forces.

32 Rozporządzenie Ministra Spraw Wewnętrznych z dnia 18 kwietnia 2012 r. w sprawie postępowania kwalifikacyjnego $w$ stosunku do osób ubiegajacych się o przyjęcie do stużby w Policji, "Journal of Laws" 2012, item 432 (from 1 January 2012 pursuant to Art. 1, point 8 of the Act of 4 March 2011 on Amendment to the Act on the Promulgation of Normative Acts and Certain Other Legal Acts and Certain Other Acts numbers of Journals of Law have been abolished).

33 See: Sprawozdanie o stanie i pracy transportu Policji w 2009, National Police Headquarters, NPHQ Police Logistics, Warszawa, March 2010. 
- reducing road traffic hazards, which results in the fall of the number of accident victims and the number of road accidents and collisions;

- increasing the influence of Police in the area of crime prevention and ensuring actions aimed at preventing perpetration of criminal offenses and petty offenses, which entails less crime and danger to citizens;

- effectively fighting the threats connected with mass events with regard to ensuring the possibility of transfer of Crime Prevention Squads and Task-Oriented Crime Prevention Sub-Squads to the places where such events take place;

- increasing the effectiveness of detection and persecution of crime and misdemeanor perpetrators;

- ensuring timely transportation and convoying of detained and convicted persons in order to carry out actions in connection with legal proceedings, in cooperation with the agencies of the prosecutor's office and courts, which will contribute to proper and effective functioning of law enforcement authorities;

- ensuring effective fighting of acts of terrorism.

Proper functioning of the Police transportation service is significant not only for ensuring public order, but it has also a considerable impact on the image of Police in the society and on the level of confidence in Police, and thereby on its effectiveness and efficacy. The tasks connected with ensuring proper organization of the transport system are performed in Police units by the transportation services, being part of logistics support service. By the end of the past decade the transportation fleet in use by the Police units comprised 20,185 vehicles, which accounted for $89 \%$ of the required quantity. It is worth noting that since 2008 there has been a change in the colours of marked police vehicles. New colours have been made compliant with the requirements of the European Union; apart from the dominating silver colour, the police car has a strip of blue reflective foil along its body with additional rectangular elements of white reflective foil, running along the upper and lower edges of the strip. There is a white inscription POLICJA on both sides of the car placed against the discriminating background of the blue strip. The basic weapons of Polish Police are at present self-loading guns _99, GLOCK, P-64, P-83. Also, the Police force has machine guns GLAUBERYT, assault rifles $G$-36, smooth-bore shot guns $12 \mathrm{~mm}$ - caliber Mosberg, Imperator, Benelli, sniper rifles $T R G-21, T R G-22, T R G-42$. Aviation components also play an important role in the structure of modern police forces. The beginning of the activity of Polish police air force formally dates back to 1996, when two units of Police Air Force, one in Krakow and one in Poznań, equipped in 2 helicopters PZL Kania, were created. ${ }^{34}$ In 2000, 11 helicopters were taken over from the disbanded Vistula Military Units of the Ministry of Internal Affairs and Administration and introduced into the structures of the police aviation for service.

34 Helicopters began to be used for police task purposes in 1965, when two helicopters Mi-4 and two helicopters SM-1 of the Transportation and Liaison Air Squadron of the Ministry of the Interior were used in the action of searching for the criminals who had run away from the prison in Krosno. Irrespective of the searches being made, along the expected route of escape of the convicted, special leaflets containing an announcement concerning the wanted fugitives were thrown from the helicopters. 
Table 1

Transport equipment assets and the degree to which the required quantity in particular groups of transportation equipment is covered

\begin{tabular}{|c|l|r|r|c||}
\hline ON. & \multicolumn{1}{|c|}{ Type of equipment } & Quantity & $\begin{array}{r}\text { Required } \\
\text { quantity }\end{array}$ & $\begin{array}{c}\text { Covered } \\
\text { quantity (\%) }\end{array}$ \\
\hline 1 & Passenger cars & 12,955 & 14,338 & $90 \%$ \\
\hline 2 & Passenger and utility cars & 695 & 845 & $82 \%$ \\
\hline 3 & Vans & 3,642 & 4,159 & $88 \%$ \\
\hline 4 & Logistics support cars & 520 & 703 & $74 \%$ \\
\hline 5 & Buses & 108 & 170 & $64 \%$ \\
\hline 6 & Special-purpose vehicles & 356 & 524 & $68 \%$ \\
\hline 7 & Motor boats & 280 & 288 & $97 \%$ \\
\hline 8 & Motorcycles and other equipment & 1,629 & 1,657 & $98 \%$ \\
\hline & Total & 20,185 & 22,684 & $89 \%$ \\
\hline
\end{tabular}

Source: Sprawozdanie o stanie i pracy transportu Policji w 2009, National Police Headquarters, Police Logistics Bureau NPHQ Warsaw, March 2010.

The current organisational structure and dislocation of forces is as follows:

- the Air Force Department of the Air Force Board of the NPHQ - Warsaw: (1 Bell-206; $3 \mathrm{Mi}-8 ; 2 \mathrm{~W}-3$ );

- PPHQ Air Force Section - Kraków (2 PZL Kania);

- PPHQ Air Force Section - Łódź (2 Mi-2);

- PPHQ Air Force Section - Poznań (2 Mi-2);

- PPHQ Air Force Section - Szczecin (2 Mi-2);

- PPHQ Air Force Section - Wrocław (2 Mi-2).

The core activities of the Police air-force are: (1) to take part in police activities, actions and operations; (2) to perform commissioned aviation tasks in accordance with the rules in effect in the Police air-force; (3) to participate in the operations aimed at counteracting crisis situations, including terrorist attacks and to mitigate and remedy the effects of such situations; (4) to cooperate with the relevant air force authorities and other organisations pursuing tasks in the scope of protecting public safety and order ${ }^{35}$. The Police Air-Force is supervised by the Head of the Police Air Force Board of the National Police Headquarters. To sum up, one can state that in entrusting to Police a significant role of one of the most important guardians of public safety and public order, the Polish State, like other modern democratic states, has equipped that formation with appropriate organisational, legal and material means and solutions, facilitating it to duly perform the tasks imposed on it.

35 See: Zarządzenie NR 1158 Komendanta Głównego Policji z dnia 17 października 2005 r. $w$ sprawie powołania oraz określenia organizacji, zakresu działania i właściwości terytorialnej stużby Lotnictwo Policji, "NPHQ Official Gazette" 2007, No. 17, item 117. 


\begin{abstract}
Public safety and public order are fundamental elements of the sphere of internal safety of the State.

The presented article, having shown the essence of and interrelationships between public safety and public order, deals with the issues of the role and tasks of the Police service as one of the most important guardians of those aspects of Poland's internal safety. The principal themes of the study focus on such issues as: the statutory tasks, organisational structures, police authorities, personnel and material assets. Apart from indicating general statutory tasks, the articles shows them also in a broader perspective, in the context of the tasks performed at particular organisational levels: the central level represented by the National Headquarters, the regional level managed by Provincial headquarters and the local level for which county headquarters and the subordinate police stations and posts are responsible. In showing the Police force as one of the most important entities ensuring public safety and public order, the special tools which Police has at its disposal, namely compact crime prevention squads and anti-terrorist units, have been described as well. Finally, the articles presents the characteristics of the personnel assets (the number of personnel, description of the length of service among particular corps) and material assets (number of vehicles, basic armament, police air-force dislocation and aircraft).
\end{abstract}

\title{
POLICJA JAKO STRAŻNIK BEZPIECZEŃSTWA I PORZĄDKU PUBLICZNEGO WSPÓŁCZESNEJ POLSKI
}

\section{STRESZCZENIE}

Bezpieczeństwo publiczne i porządek publiczny to elementy fundamentalne dla sfery wewnętrznego bezpieczeństwa państwa. Prezentowany artykuł po ukazaniu istoty i wzajemnych relacji pomiędzy bezpieczeństwem publicznym a porządkiem publicznym podejmuje kwestię roli i zadań Policji jako jednego z najważniejszych strażników tych aspektów wewnętrznego bezpieczeństwa Polski. Zasadnicze wątki opracowania koncentrują się wokół takich zagadnień jak; zadania, struktury organizacyjne, organy policyjne, potencjał personalny i materialny. Oprócz wskazania generalnych zadań ustawowych artykuł ukazuje je także w poszerzonej perspektywie w kontekście rozpisania ich na poszczególne poziomy organizacyjne. Poziom centralny reprezentowany przez Komendę Główną, poziom regionalny zajmowany przez Komendy Wojewódzkie i poziom lokalny za który odpowiadają Komendy Powiatowe oraz podległe im komisariaty i posterunki. Wskazując na Policję jako jeden z ważniejszych elementów zapewniających bezpieczeństwo publiczne i porządek publiczny w Polsce ukazano także specjalne narzędzia jakimi ona dysponuje czyli zwarte oddziały prewencji i ogniwa antyterrorystyczne. Artykuł zamyka charakterystyka potencjału personalnego (liczba, stażu służby, rozmieszczenie w poszczególnych korpusach) oraz materialnego (ilość środków transportu, zasadnicze uzbrojenie, rozmieszczenie i stan posiadania lotnictwa policyjnego). 